\title{
PERMANENT TRANSLOCATION HETEROZYGOSITY IN VISCUM ALBUM AND V. CRUCIATUM: SEX ASSOCIATION, BALANCED LETHALS, SEX RATIOS
}

\author{
B. A. BARLOW \\ School of Biological Sciences, Flinders University, Adelaide, South Australia 5042 \\ D. WIENS, C. WIENS, W. H. BUSBY \\ Department of Biology, University of Utah, Salt Lake City, Utah 84112 \\ and \\ C. BRIGHTON \\ Jodrell Laboratory, Royal Botanic Gardens, Kew, Richmond, Surrey 5W9 3DS
}

Received 19.iv.77

\section{SUMmary}

Permanent translocation heterozygosity is confirmed in $V$. album in Europe, Japan, and California (where it is introduced), and reported for the first time in $V$. cruciatum from Israel. In $V$. album meiotic associations of

$$
4 \mathrm{II}+\odot \mathrm{IV}+\odot \mathrm{VIII}, 5 \mathrm{II}+\odot \mathrm{X} \text {, and } 6 \mathrm{II}+\odot \mathrm{VIII}
$$

are reported in male plants; in female plants meiotic configurations of 10II, 8II $+\odot \mathrm{IV}, 7 \mathrm{II}+\odot \mathrm{VI}, 6 \mathrm{II}+\odot \mathrm{VIII}$ were discovered. In Japanese populations of $V$. album male plants have $5 \mathrm{II}+\odot \mathrm{X}$ and $6 \mathrm{II}+\odot$ VIII, but female plants have $6 \mathrm{II}+\odot \mathrm{VIII}$ and $7 \mathrm{II}+\odot \mathrm{VI}$, indicating that in this population translocation heterozygosity may be maintained by a system of balanced lethals similar to those in Onagraceae. Other populations of $V$. album and $V$. cruciatum preserve permanent heterozygosity through a sex associated system previously described in other species. Female predominant sex ratios ranging from 0.49 to 0.24 occur in both $V$. album and $V$. cruciatum.

\section{Introduction}

THE high incidence of translocation heterozygosity in some dioecious African species of Viscum has been described previously (Barlow and Wiens, 1975, 1976; Wiens, 1975). In species such as $V$. fischeri Engl. and V. hildebrandtii Engl. there are large, permanent translocation complexes maintained through sex association, i.e., the male plants are heterozygous and the female plants homozygous. Further complexity occurs by the addition of floating translocations which are not sex associated and may thus occur in the heterozygous state in both male and female plants. In some cases, but not all, we have found biased sex ratios occurring in species with translocation heterozygosity, and have suggested that the translocations may have different adaptive roles in different species.

Further extensive studies (unpublished data) have shown that all dioecious African species of Viscum analysed in detail exhibit translocation heterozygosity, and that most of these species have permanent sex associated complexes. Thus a fundamental relationship appears to exist between translocation heterozygosity and dioecy in African species of Viscum. When first discovered in $V$. fischeri sex associated translocation heterozygosity was assumed to be a case of fortuitous translocations, in a dioecious species, 
involving the chromsome pair carrying the sex determination factors. We now believe that translocations have been involved in the evolution of dioecy in Viscum, presumably by altering linkage relationships of non-allelic factors for maleness and femaleness. Translocations may thus play a causal role in the origin of a stable dioecious condition in Viscum. Charlesworth and Charlesworth (1977) have argued on general grounds that dioecy may be expected to involve non-allelic sex determination factors. A detailed analysis of the origin of dioecy in Viscum will be presented separately.

Supernumerary chromosomes also occur in several African species. Their origin may be linked with the frequent occurrence of translocations (John, 1976), but their widespread persistence may indicate some, as yet unidentified, adaptive role in the dioecious species of Viscum.

Since translocation heterozygosity appears to be characteristic of all dioecious sub-Saharan species of Viscum in Africa, and may be causally associated with dioecy in the genus, it is of interest to determine the nature and extent of this phenomenon in species outside this region. Preliminary studies have been made of a few Madagascan species (Wiens, 1975) and although the occurrence of translocation heterozygosity has not been demonstrated, it is to be expected. In this paper we present some observations on two species, $V$. album $\mathrm{L}$. and $V$. cruciatum Boiss., which are distributed through Europe and Asia. Both are dioecious, have the same chromosome number $(2 n=20)$, represent end points of a long aneuploid reduction series in the genus (Wiens, 1975), and have extensive east-west distributions (Danser, 1941). Viscum album occurs from the United Kingdom through Europe to southern Asia and Japan; $V$. cruciatum ranges from southern Europe and north Africa to the Middle East and Pakistan. Although $V$. album, the traditional mistletoe of Western folklore, has been studied extensively (Tubeuf, 1923), several relevant aspects of its biology have only recently been discovered. For example, female biased sex ratios in adult populations of 0.49 and 0.40 are now known from England (Showler, 1974) and Sweden (Walldén, 1961) respectively. More importantly, Mechelke (1976) has demonstrated that male plants from Germany are heterozygous for a ring of eight chromosomes and the female plants are homozygous. Translocation heterozygosity was not observed in earlier meiotic studies of $V$. album (Pisek, 1923; Steindl, 1935) but the possibility of its occurrence was suggested to us by the biased sex ratio (Barlow and Wiens, 1976).

\section{Materials AND methods}

Flower buds from male and female plants were fixed in absolute ethanol/ acetic acid $(3: 1)$ and stored in 95 per cent ethanol at $-15^{\circ} \mathrm{C}$ when possible. The chromosome constitution of male plants was studied from meiosis in pollen mother cells squashed in aceto carmine. In female plants the chromosome associations were determined from meiosis in embryo sac mother cells. The small basal portion of the ovary containing the sporogenous tissue was dissected out, macerated on a slide in a drop of 45 per cent acetic acid containing 1 per cent $\mathrm{HCl}$ for $2-3$ minutes at $60^{\circ} \mathrm{C}$, and very lightly squashed in aceto carmine. Voucher specimens have been deposited in the herbarium of the University of Utah and the State Herbarium of South Australia. 


\section{Results}

Our studies in $V$. album confirm Mechelke's (1976) karyological results, but cover a larger part of the distribution, and show translocation polymorphisms not previously reported (table 1). Populations from the extremes of the geographic range (United Kingdom and Japan) only show associations of $5 \mathrm{II}+\odot \mathrm{X}$ (ring-of-ten) and $6 \mathrm{II}+\odot$ VIII in male plants in the materials so far studied. A floating $\odot \mathrm{IV}$ also exists in both male and female plants in the California population [ $V$. album has become naturalised near Sebastopol, California, following introduction from Europe (Scharpf and Hawksworth, 1976)] and conforms with Mechelke's findings from Germany.

TABLE 1

Chromosome constitution of Viscum album and V. cruciatum

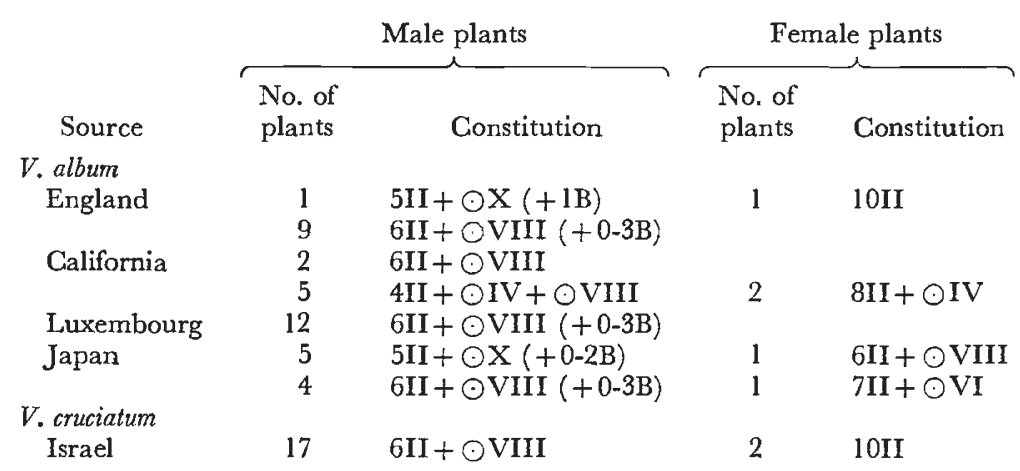

Supernumerary chromosomes occur in populations from Europe and Japan. The size and morphology indicate that at least three different supernumerary chromosomes are present, but their occasional meiotic pairing indicates that they are at least partly homologous.

The most significant observation, however, is the possible occurrence in Japanese populations of $V$. album of permanent translocation complexes in female as well as male plants (table 1). If further studies show that female plants in these populations are consistently heterozygous (i.e., with $6 \mathrm{II}+\odot \mathrm{VIII}$ or $7 \mathrm{II}+\odot \mathrm{VI})$, then the Japanese populations of $V$. album will be different, in this respect, from all other species of the genus so far studied.

The meiotic configurations in $V$. cruciatum observed in Israel are consistently $6 \mathrm{II}+\odot$ VIII in male plants (table 1 ). The female plants are structurally homozygous with 10II, and translocation heterozygosity is presumably maintained through sex association as is typical of other dioecious species. Viscum cruciatum is interesting, however, because of the apparent constancy of the translocation complex. Only in $V$. fischeri is a single invariable translocation system known in Viscum. Furthermore, the translocation ring of eight in $V$. cruciatum is the same size as the most commonly found configuration in $V$. album. Viscum album and $V$. cruciatum are apparently closely related and it would be interesting to know the extent of karyotypic repatterning between the two species and whether the translocation ring of eight involves the same chromosomes. 
Our observations of female predominant sex ratios in adult populations of $V$. album ranging from approximately 0.5 to 0.25 (table 2) are generally consistent with earlier reports (Showler, 1974; Walldén, 1961), but contrast with the results of Mechelke (1976), who reported a ratio of approximate unity. The female predominant sex ratio of 0.24 observed in $V$. album from Japan is the most extreme thus far observed in the genus. The only data so far obtained for $V$. cruciatum are from Israel, and also show a highly skewed female predominant sex ratio $(0 \cdot 27)$.

TABLE 2

Sex ratio in Viscum album and $\mathrm{V}$. cruciatum

$\begin{array}{lccc}\text { Source } & \text { Male plants } & \text { Female plants } & \text { Sex ratio } \\ \text { V. album } & & & \\ \text { England } & 28 & 65 & 0 \cdot 43 \\ \text { California } & 73 & 150 & 0 \cdot 49 \\ \text { Luxembourg } & 39 & 105 & 0 \cdot 37 \\ \text { Japan } & 12 & 49 & 0 \cdot 24 \\ \begin{array}{l}\text { V. cruciatum } \\ \text { Israel }\end{array} & 21 & 77 & 0 \cdot 27\end{array}$

\section{Discussion}

If further studies confirm the occurrence of permanent translocation heterozygosity in both male and female plants in the Japanese populations, then it may be necessary to postulate a system of balanced lethals, similar to those known in Onagraceae (see discussion by John and Lewis, 1975) and Isotoma (James, 1970), to maintain the system. The translocation complexes maintained by sex association in all other species of Viscum so far studied do not require such a system. However, because the translocation rings may be of different sizes in male and female plants, some relationship between sex determination and translocation heterozygosity is suggested.

One model of translocation heterozygosity maintained through a balanced lethal system which explains our observations from the Japanese population of $V$. album is shown in fig. 1. For the reasons given above, non-allelic male- and female-determining factors ( $\mathrm{Y}$ and $\mathrm{X}$ respectively in fig. 1) have been assumed, but it is possible to construct a similar model on the assumption of allelic sex determination factors. Only two male and two female translocation types would be visible cytologically, although among male plants there would be two cytotypes with $5 \mathrm{II}+\odot \mathrm{X}$ and two with 6 II $+\odot$ VIII. The system would depend on balanced recessive lethals $\left(l_{1}\right.$ and $\left.l_{2}\right)$ for its stability. The minimum number of translocations required by the model is five. This exceeds by only one the minimum number required to produce a ring of ten.

The data presented in this study and that of Mechelke (1976) indicate that in European populations of $V$. album the females are structurally homozygous as far as the sex associated complex is concerned. This difference between the chromosome system of the Japanese population and that of the European populations may be primarily a difference in the operation or stability of the balanced lethal system. If, in the model presented above, for example, a non-lethal mutant is introduced at the site of lethal gene $l_{2}$, then the balanced lethal system will break down and the 

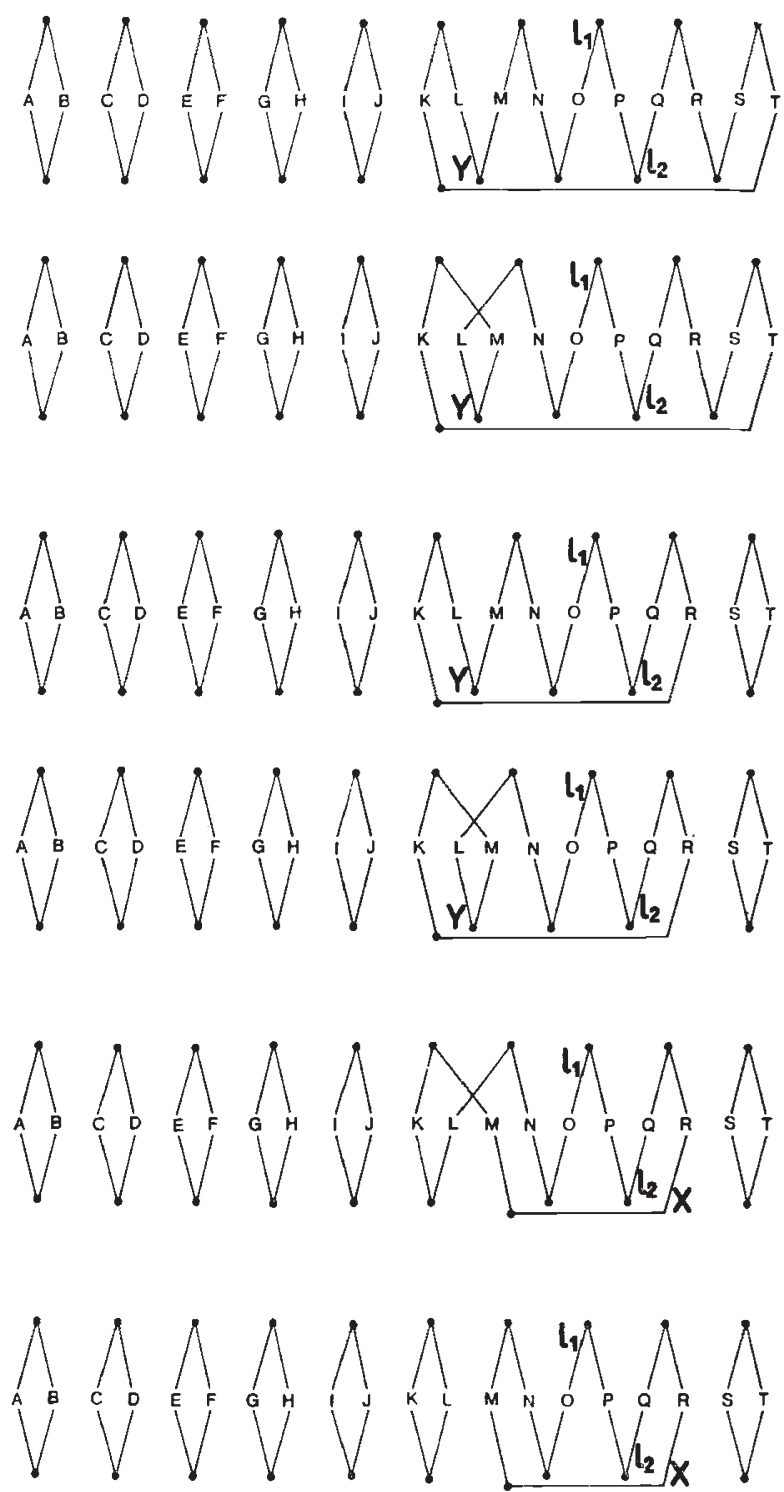

FIG. 1.-Possible chromosome constitution of the Japanese population of V. album. First and second rows, male plants with $5 \mathrm{II}+\odot \mathrm{X}$. Third and fourth rows, male plants with $6 I I+\odot$ VIII. Fifth row, female plant with $6 I I+\odot$ VIII. Bottom row, female plant with 7II $+\odot$ VI. Possible locations of male- and female-determining factors $\left(\mathrm{Y}\right.$ and $\mathrm{X}$ respectively) and of recessive balanced lethal genes $\left(\mathrm{l}_{1}\right.$ and $\left.\mathrm{l}_{2}\right)$ are shown.

population will shift to a new equilibrium in which all female plants are homozygotes with $10 \mathrm{II}$ and all male plants are heterozygotes, in this case with $8 \mathrm{II}+\odot \mathrm{IV}$. The balanced lethal system, if it exists in $V$. album, may therefore represent a stage in the evolution of the sex associated translocation system, and perhaps in the evolution of dioecy in the genus. This possibility will be considered further in a subsequent paper. 
The highly skewed female predominant sex ratios in $V$. album make the report of apomixis (agamospermy) by Dobrescu and Ghenciu (1974) from Romania especially interesting. In populations of $V$. album with very few males it might be argued that pollination [presumably wind (Hatton, 1966)] would become ineffective and thus place a high selective premium on mutations favouring agamospermy in female plants. Agamospermy, if it exists in Viscum, may thus be an adaptive consequence of a female predominant sex ratio which has been driven to a point of reproductive inefficiency. Cases of parthenogenetic vertebrates apparently derived from sexual populations with skewed female biased sex ratios are known (Cuellar, 1974).

These results show that the interrelationships in Viscum between translocation heterozygosity, supernumerary chromosomes, dioecy, and sex ratio extend beyond the African species. Studies of the possible causal interrelationships between these factors are continuing.

Acknowledgments.-These studies were supported by grants from the U.S. National Science Foundation and the Flinders University Research Committee. We thank Dr A. Moriya, Utsunomiya University, Japan, and Mr David Heller and Ms Batia Pazy, Hebrew University of Jerusalem, for assistance in the field. We also thank Dr U. Plitmann and Prof. N. Feinbrun of Hebrew University for the use of laboratory facilities.

\section{REFERENCES}

BARLOW, B. A., AND WIENS, D. 1975. Permanent translocation heterozygosity in Viscum hildebrandtii Engl. and V. engleri Tiegh. (Viscaceae). Chromosoma (Berl.), 53, 265-272.

BARLOW, B. A., AND WIENS, D. 1976. Translocation heterozygosity and sex ratio in Viscum fischeri. Heredity, 37, 27-40.

CHARLESWORTH, B., AND CHARLESWORTh, D. 1977. A model for the evolution of dioecy and gynodioecy. Amer. Nat. (in press).

CUELLAR, o. 1974. On the origin of parthenogenesis in vertebrates: the cytogenetic factors. Amer. Nat., 108, 625-648.

DANSER, B. 1941. The British-Indian species of Viscum revised and compared with those of South-Eastern Asia, Malaysia, and Australia. Blumea, 4, 261-319.

DOBREsCU, C., AND GHENGIU, v. 1974. Observațü cu privire la reproducerea Viscului (Viscum album L. ssp. album) in populaţüle de pe valea vāmeșoaei-dealul repedea (iași) (Notă preliminară). (With French summary.) Anal. Stüntif. Ale. Univ. "AL. I. Cuza" Din Iasi Sect. II. A. Biol., 22, 327-330.

hatton, R. H. s. 1966. Pollination of mistletoe (Viscum album L.). Proc. Linnean Soc. Lond., $176,67-76$.

JAMES, s. н. 1970. Complex hybridity in Isotoma petraea. II : Components and operation of a possible evolutionary mechanism. Heredity, 25, 53-77.

јонN, в. 1976. Population Cytogenetics. Edward Arnold, London.

JOHn, B., AND LEwIS, к. 1975. Chromosome Hierarchy. Clarendon Press, Oxford.

MECHELKE, F. 1976. Sex-correlated complex heterozygosity in Viscum album L. Naturw., 8,390 .

PISEK, A. 1923. Chromosomenverhältnisse, Redukionsteilung und Revision der Keimentwicklung der Mistel (Viscum album). Fahrb.f. Wiss. Bot., 62, 1-19.

SCHARPF, R. F., AND HAWKSWORTH, F. 1976. Luther Burbank introduced European mistletoe into California. Plant Dis. Rept., 60, 740-742.

showler, k. 1974. Raising mistletoe (Viscum album) from seed. 7. Roy. Hort. Soc., 99, 30-37.

steindL, F. 1935. Pollen and Embryo-sackentwicklung bei Viscum album L. und Viscum articulatum Burm. Schweiz. Bot. Gesell. Ber., 44, 343-388.

tubeur, c. von. 1923. Monographie der Mistel. Oldenbourg, Berlin.

WALldÉN, B. 1961. Misteln vid des Nordgräns. Sv. Bot. Tidskr., 55, 427-549.

wIENs, D. 1975. Chromosome numbers in African and Madagascan Loranthaceae and Viscaceae. Bot. F. Linnean Soc., 71, 295-310. 